\title{
ІНФОРМАЦІЙНІ ТЕХНОЛОГЇ̈
}

\author{
ИНФОРМАЦИОННЫЕ ТЕХНОЛОГИИ
}

INFORMATION TECHNOLOGY

\author{
V. Y. SOKOL, P. Y. SAPRONOV, M. O. BILOVA
}

\section{USING CLOUD PLATFORMS TO BUILD DISTRIBUTED LEARNING MANAGEMENT SYSTEMS}

Distributed systems have problems with downtime, data loss during malfunctions, scalability and efficient use of computing resources. At the same time in the learning and training process, the use of a distributed system has the advantage of data processing: storage of information about students, construction of training courses, verification of passed material, etc. The problems of scaling and efficient use of resources in distributed learning management systems are investigated in this research. Cloud platforms for hosting the system, such as Amazon Web Services, Microsoft Azure, Google Cloud Platform and DigitalOcean are reviewed. Problems and features of a scalability in cloud computing are discussed. Methods, scaling and load balancing algorithms for the efficient use of computing resources are proposed. According to the list of advantages, the DigitalOcean platform was selected for the investigation. DigitalOcean provides cloud servers that can be used for quick creation of the new virtual machines for the projects. These servers allow to fully control the web hosting environment at the same time that the user pays only for the resources used. The main goal of DigitalOcean is to use a solid-state drive (SSD) to create a user-friendly platform that will allow clients to migrate projects to and from the cloud, increasing productivity with high speed and efficiency. As a result of analyzing information on existing technologies, approaches and methods for using cloud platforms in distributed systems, they have been applied to develop a solution to reduce downtime for a distributed adaptive Learning Management System (LMS) It is concluded that the use of cloud platforms for the construction of distributed LMS a practice that allows to use only the required amount of computing capacity. It is proven, that the implementation of the proposed solution into the work of adaptive LMS will improve its efficiency by reducing the time of the content delivering.

Keywords: cloud platforms, distributed systems, cloud computing, scaling, load balancing, virtualization, containerization.

\section{В. Є. СОКОЛ, П. Ю. САПРОНОВ, М. О. БІЛОВА \\ ВИКОРИСТАННЯ ХМАРНИХ ПЛАТФОРМ ДЛЯ ПОБУДОВИ РОЗПОДІЛЕНИХ СИСТЕМ УПРАВЛІННЯ НАВЧАННЯМ}

Розподілені системи мають проблеми з простоєм, втратою даних під час несправностей, масштабованістю та ефективним використанням обчислювальних ресурсів. Водночас у процесі навчання та тренінгу використання розподіленої системи має перевагу обробки даних: зберігання інформації про студентів, побудова навчальних курсів, перевірка зданого матеріалу тощо. У даній роботі досліджено проблеми масштабування та ефективного використання ресурсів в розподілених системах управління навчанням. Розглянуто хмарні платформи для розміщення системи, такі як Amazon Web Services, Microsoft Azure, Google Cloud Platform та DigitalOcеan. Розглянуто проблеми та особливості масштабованості хмарних обчислень. Запропоновано методи, алгоритми масштабування та балансування навантаження для ефективного використання обчислювальних ресурсів. Відповідно до переліку переваг, для дослідження було обрано платформу DigitalOcean. DigitalOcean надає хмарні сервери, які можна використовувати для швидкого створення нових віртуальних машин для проектів. Ці сервери дозволяють повністю контролювати середовище веб-хостингу, при цьому користувач платить лише за використані ресурси. Основною метою DigitalОсеап є використання твердотільного накопичувача (SSD) для створення зручної платформи, яка дозволить клієнтам перемішувати проекти в хмару та 3 неї, підвищуючи продуктивність з високою швидкістю та ефективністю. В результаті аналізу інформації про існуючі технології, підходи та методи використання хмарних платформ у розподілених системах було розроблено рішення щодо скорочення простоїв розподіленої адаптивної системи управління навчанням (LMS). Зроблено висновок про те, що використання хмарних платформ для побудови розподілених LMS - це практика, яка дозволяє використовувати лише необхідну кількість обчислювальних потужностей. Доведено, що впровадження запропонованого рішення в роботу адаптивної LMS підвищить її ефективність за рахунок скорочення часу доставки контенту.

Ключові слова: хмарні платформи, розподілені системи, хмарні обчислення, масштабування, балансування навантаження, віртуалізація, контейнеризація.

\section{В. Е. СОКОЛ, П. Ю. САПРОНОВ, М. А. БЕЛОВА \\ ИСПОЛЬЗОВАНИЕ ОБЛАЧНЫХ ПЛАТФОРМ ДЛЯ ПОСТРОЕНИЯ СИСТЕМ УПРАВЛЕНИЯ РАСПРЕДЕЛЕННЫМ ОБУЧЕНИЕМ}

Распределенные системы имеют проблемы с простоем, потерей данных при неисправностях, масштабируемостью и эффективным использованием вычислительных ресурсов. В то же время в процессе обучения и тренинга использование распределенной системы имеет преимущества обработки данных: хранение информации о студентах, построение учебных курсов, проверка сданного материала и тому подобное. В данной работе исследованы проблемы масштабирования и использования ресурсов в распределенных системах управления обучением. Рассмотрены облачные платформы для размещения системы, такие как Amazon Web Services, Microsoft Azure, Google Cloud Platform и DigitalOcean. Рассмотрены проблемы и особенности масштабируемости облачных вычислений. Предложены методы, алгоритмы масштабирования и балансировки нагрузки для эффективного использования вычислительных ресурсов. В соответствии с перечнем преимуществ, для исследования была выбрана платформа DigitalOcean. DigitalOcean предоставляет облачные серверы, которые можно

(C) V. Y. Sokol, P. Y. Sapronov, M. O. Bilova, 2020

Вісник Національного технічного університету «ХПІ». Серія: Системний

аналіз, управління та інформаційні технології, № 2 (4)’2020 
использовать для быстрого создания новых виртуальных машин для проектов. Эти сервера позволяют полностью контролировать среду вебхостинга, при этом пользователь платит только за использованные ресурсы. Основной целью DigitalOcеan является использование твердотельного накопителя (SSD) для создания удобной платформы, которая позволит клиентам перемещать проекты в облако и из него, повышая производительность с высокой скоростью и эффективностью. В результате анализа информации о существующих технологиях, подходах и методах использования облачных платформ в распределенных системах было разработано решение по сокращению простоев распределенной адаптивной системы управления обучением (LMS). Сделан вывод о том, что использование облачных платформ для построения распределенных LMS - это практика, которая позволяет использовать только необходимое количество вычислительных мощностей. Доказано, что внедрение предложенного решения в работу адаптивной LMS повысит ее эффективность за счет сокращения времени доставки контента.

Ключевые слова: облачные платформы, распределенные системы, облачные вычисления, масштабирование, балансировка нагрузки, виртуализация, контейнеризация.

Introduction. The emergence of distributed systems in the field of IT technology was because one computer could not process all the information that comes every day with the development of technology.

However, distributed systems still have problems with downtime, loss of important data during malfunctions, scalability and the most efficient use of computing resources. Over time, platforms have emerged to help solve this problem by providing cloud computing services. Cloud technologies (or cloud computing) are distributed digital data processing technologies that provide computer resources to the Internet user as an online service.

For the training system, the use of a distributed system has the advantage of data processing: storage of information about students, construction of training courses, verification of passed material, etc. When using cloud computing in such systems, mobility is an advantage. Therefore, a person can access training materials, courses, or test their knowledge from anywhere on the planet with Internet access and the device they need.

Learning management systems have become an integral part of the e-learning content development process, especially if there are many trainers and few trainers in the school or not, so one of these systems needs to be used to facilitate the tasks and refine the learning process.

Taking into account integrated knowledge-based methodological framework for staff-training in ITcompanies $[1 ; 2]$, the purpose of this work is to explore the technologies, approaches, and methods used in cloud platforms. Develop a solution to reduce downtime, scalability, and use only the required computing resources at any given time that can be deployed in distributed adaptive Learning Management System (LMS) [3].

Existing platform and technologies overview. Overview of cloud platforms. The hardware and operating environment of a server in an Internet-based datacenter. The system software components (OS, virtual machine monitor, etc.) are called the "cloud stack" [2].

When using cloud platforms by clients, only the organization of the workplace (computer/laptop/tablet) is required, regardless of the location. The only condition is the availability of Internet access. The client (user of the cloud platform) is only responsible for the administration of its applications and software.

Amazon Web Services is a subsidiary of Amazon.com, which provides a cloud-based leasing platform to individuals, companies, and governments on a paid subscription basis. The technology allows subscribers to have a complete virtual cluster of computers, which is always accessible via the Internet.

Microsoft Azure is a cloud platform and infrastructure of Microsoft Corporation designed for cloud computing developers and designed to streamline the process of creating online applications. A close competitor to AWS with an extremely capable cloud infrastructure. The Azure platform is also working with data centers.

Google Cloud Platform is Google's suite of cloud services that run on the same infrastructure that Google uses for its end-user products, such as Google Search and YouTube. Google later entered the cloud market and has no enterprise focus to help attract corporate clients. But his technical knowledge is deep, and his leading capabilities in deep learning and artificial intelligence, machine learning, and data analytics are significant strengths.

DigitalOcean is a US-based hosting company focused on helping developers launch more applications faster and easier. DigitalOcean provides cloud servers that developers can use to quickly create new virtual machines for their projects. They allow you to fully control the web hosting environment at the same time that the user pays only for the resources used. DigitalOcean's ultimate goal is to use a solid-state drive (SSD) to create a user-friendly platform that will allow their clients to migrate projects to and from the cloud, increasing productivity with high speed and efficiency [3].

Scalability in cloud computing. Scalability is the unique feature of cloud computing where dynamic provisioning of the resources is being done by the clients themselves with in the real time slice. Vertical scalability is the ability to increase the capacity of existing single hardware or software by adding more resources to the same server or hardware. Horizontal cloud scalability is the ability of the system or resources to connect multiple hardware or software entities, such as servers or networks so that they work as a one logical unit [4].

Load balancing. Load balancing is a method that has helped networks and resources, to provide maximum throughput with minimal response time [5].

In the static load balancing method, the performance of nodes is determined at the beginning of execution. Then, depending on their performance, the workload is distributed at the outset by the master node. The slave process calculates its distributed work and transmits its result to the master. The task is always performed on the node to which it is assigned.

Dynamic load balancing differs from static algorithms in that the workload is distributed between nodes at runtime. The wizard assigns new processes to subordinates based on the newly collected information. Unlike static algorithms, dynamic algorithms distribute processes dynamically when one of the processors becomes under load.

Virtualization. The creation of isolated environments within a single physical device. Each environment looks 
like a separate computer with its characteristics, such as memory, processor and so on. This environment is called a set of logical resources [8].

Containerization. An alternative to full machine virtualization, which involves encapsulating the program into a container with its operating environment. This provides many benefits of downloading the application to a virtual machine since the application can be run on any physical machine without having to worry about dependencies.

Proposed approach. Choosing a cloud platform. Among all cloud platforms considered for use in a distributed system, DigitalOcean was selected. This platform has several significant advantages over other platforms:

- uptime $99.99 \%$;

- convenient tariff plan for the use of resources payment only for what they used;

- IaaS is a provider of computing resources, so it is possible to adjust the distribution of resources according to needs [9];

- the ability to get computing resources quickly by deploying the required number of virtual machines or "drops»;

- the use of solid-state SSDs, which raises the speed of cloud computing on the platform;

- use of KVM (Kernel-based Virtual Machine) hypervisor $[10,11]$.

Scaling the system. When reviewing scaling methods for a distributed system, two main ones were selected horizontal and automatic, and manual as a secondary.

The horizontal method is best suited for running LMS in the cloud since it is easier to create new virtual machines on the platform during high load and transfer to them the load that arises from systems upon request. If you take the vertical method, you need to create a new virtual machine of larger size and transfer all the data to it and deploy it in the cloud. This means that the system may not be available for some time, so users will not be able to work with it [12]

The second main method is automatic. It will allow you to create new computing units to distribute the increased system load in the cloud.

We will also use the manual method as an auxiliary. After all, if the system administrator knows that the load will increase, then he can add new virtual machines himself or remove if some of them are no longer in use.

Load balancing in the system. Throttled load balancing method was chosen for system load balancing (fig. 1).

The load balancer (LB) maintains a table of virtual machine indexes, as well as their states (Available or Busy). The client/server first requests the data center to find a suitable virtual machine (VM) to perform the recommended task. The data center requests a LB to distribute the virtual machine. The LB scans the index table from above until the first available virtual machine is found or the index table is completely scanned.

If a virtual machine is found, the data center passes the request to the virtual machine identified by the identifier. Also, the data center confirms the load balancing of the new distribution, and the data center appropriately revises the index table. When processing a client request, if the corresponding VM is not found, the LB returns " -1 " to the data center. The center request is processed by the data center.

This choice is due to the following factors use only the required computing resources, simple implementation and speed of execution.

At the moment, this algorithm is optimal for our system. But it should be noted that in the future, with

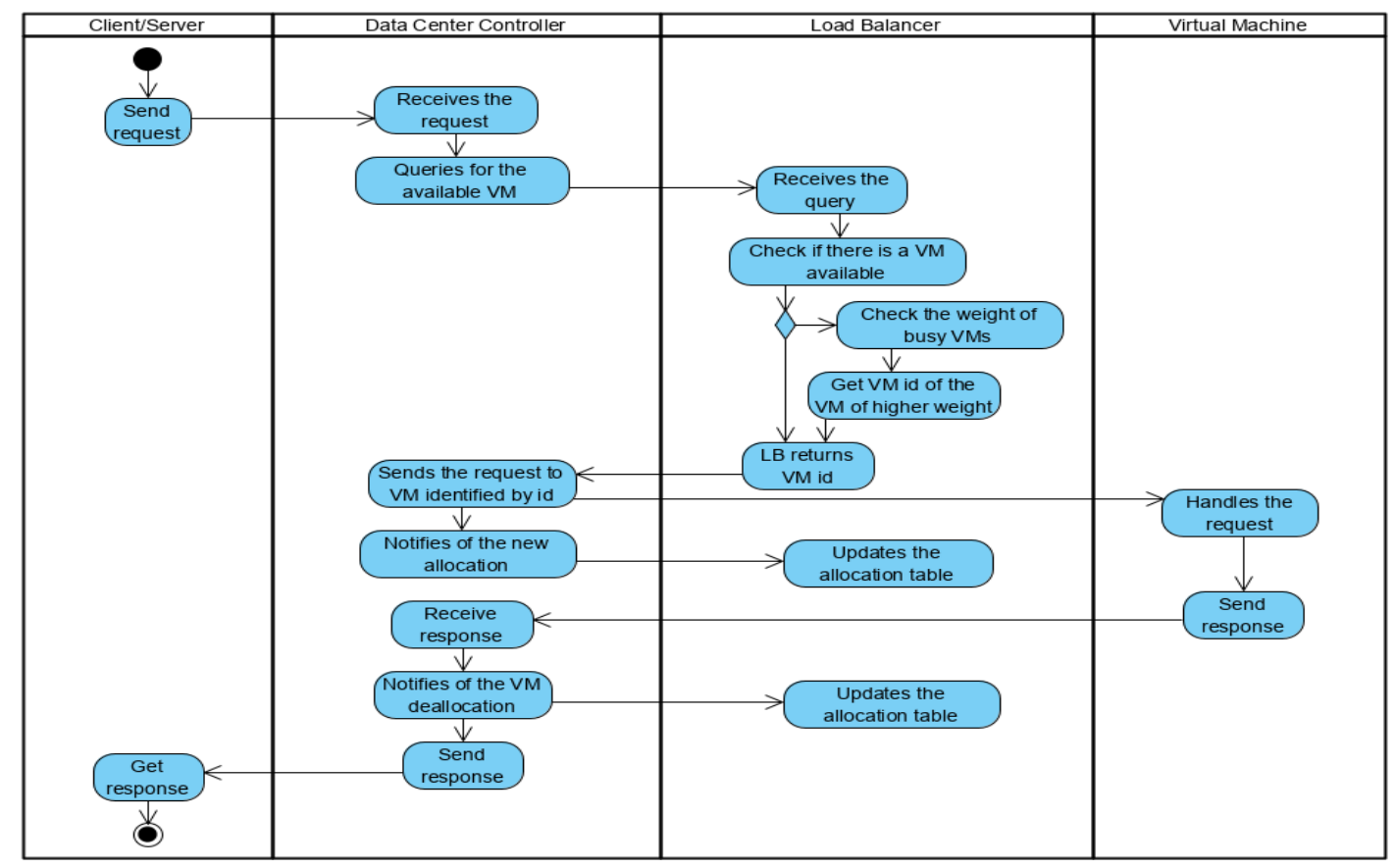

Fig. 1. Activity diagram for throttled load balancing 
system scaling, a more sophisticated algorithm will have to be used to efficiently use all computing resources.

Deployment in the cloud. The chosen cloud platform is DigitalOcean, which provides computing units called drops (fig. 2). To ensure maximum data security and the fastest data processing in the cloud, we will use containerization in a virtual machine. Containerization will be provided by Docker Compose, as the system consists of several components (fig. 3). Also, to create containers, we will create virtual machines that have a specially designed OC for the best Docker support [13].

Comprasion of solutions. Let's compare the proposed solution with the solution where vertical scaling will be present. When using this scaling method, we need to move all the data from one virtual machine to another with higher characteristics (CPU, RAM, hard disk). In this case, LMS will be in downtime for a certain time:

$$
t_{\text {downtime }}=t_{\text {allocation }}+t_{\text {transfer }} \text {, }
$$

where $t_{\text {downtime }}-$ downtime for LMS;

$t_{\text {allocation }}$ - time for hypervisor to allocate resources for $\mathrm{VM}$;

$t_{\text {transfer }}-$ time for transferring data from one VM to another.

Moreover, time for transferring data from one VM to another growing as more size of data is.

At table 1 we can find a simple comparison between the data size of VM and time for copying its data to another VM.

Here you can clearly see that the time to copy data is growing along with the volume of this data. Accordingly,

In the proposed solution, the downtime time formula remains the same (1), but the data transfer time will be constant, because it is limited by a certain template size of our virtual machine. Now we can get the efficiency and availability of the proposed solution (2):

$$
E f=\left(\frac{t_{\mathrm{vert}}}{t_{\mathrm{hor}}}-1\right) \cdot 100 \%,
$$

where $E f$ - efficiency of the proposed solution; $t_{\text {vert }}$ - time for transferring data with vertical method;

$t_{\text {hor }}$ - time for transferring data with vertical method, we set it to 86 , if we use $1024 \mathrm{MB}$ template of VM for deploy.

with each change of VM, the downtime will increase.

Table 1 - Dependency between time and data size

\begin{tabular}{|c|c|}
\hline Size(MB) & Time(secs) \\
\hline 32 & 10 \\
\hline 64 & 14 \\
\hline 128 & 24 \\
\hline 256 & 40 \\
\hline 512 & 60 \\
\hline 1024 & 86 \\
\hline 2048 & 115 \\
\hline 4096 & 148 \\
\hline
\end{tabular}

Table 2 presents the efficiency calculations for two cases in which it is necessary to change a virtual machine that has a larger volume. You can see how the efficiency of solutions using horizontal scaling is growing in comparison with vertical.

Table 2 - Calculation of efficiency

\begin{tabular}{|l|l|c|}
\hline $\boldsymbol{t}_{\text {vert }}$ & $\boldsymbol{t}_{\text {hor }}$ & $\boldsymbol{E} \boldsymbol{f}$ \\
\hline 115 & 86 & $43,75 \%$ \\
\hline 148 & 86 & $85,00 \%$ \\
\hline
\end{tabular}

These data are illustrated in more detail in Fig. 4.

Where $y$-axis is Efficiency and $x$-axis is the size of data in VM growth in the vertical method.

The implementation of this solution into the work of adaptive LMS will improve its efficiency. Now users will not need to wait more and more times each time before they can again access their training courses. Of course, increase their effectiveness during training [1].

Conclusions. The use of cloud platforms for the construction of distributed systems is a practice that allows to use only the required amount of computing capacity. This way you can focus on other aspects of the system.

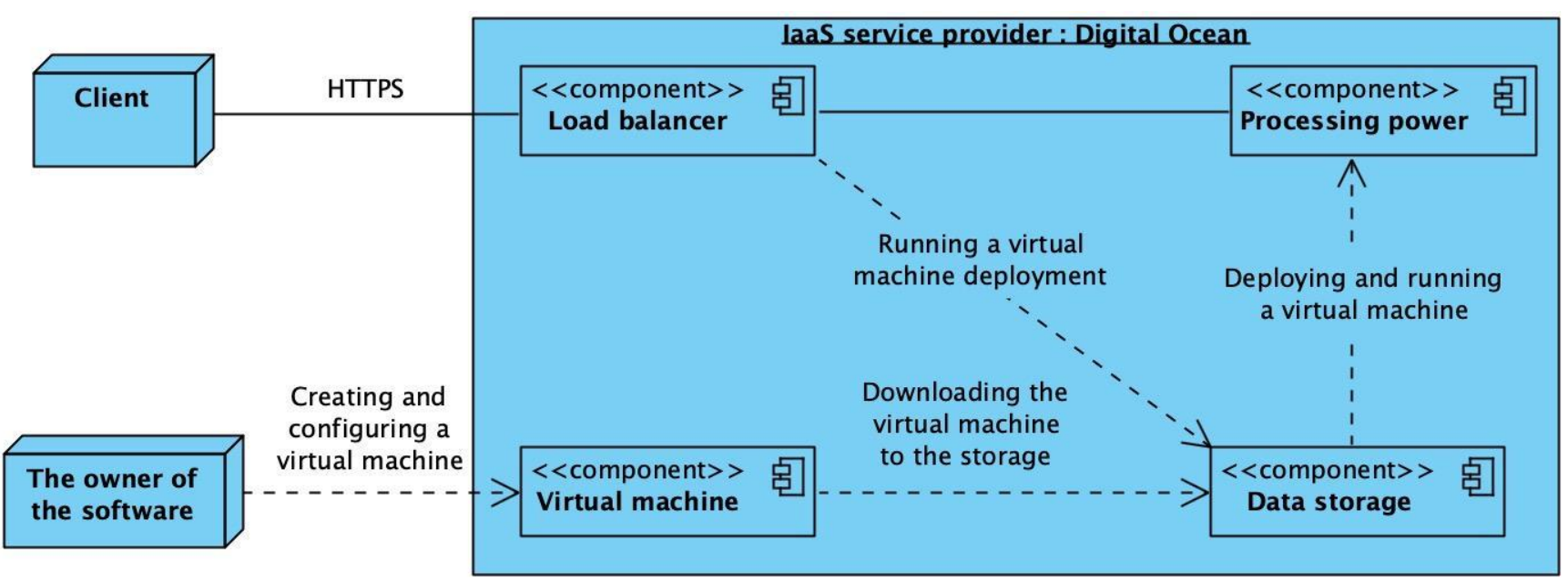

Fig. 2. Model of system operation using Digital Ocean cloud platform 


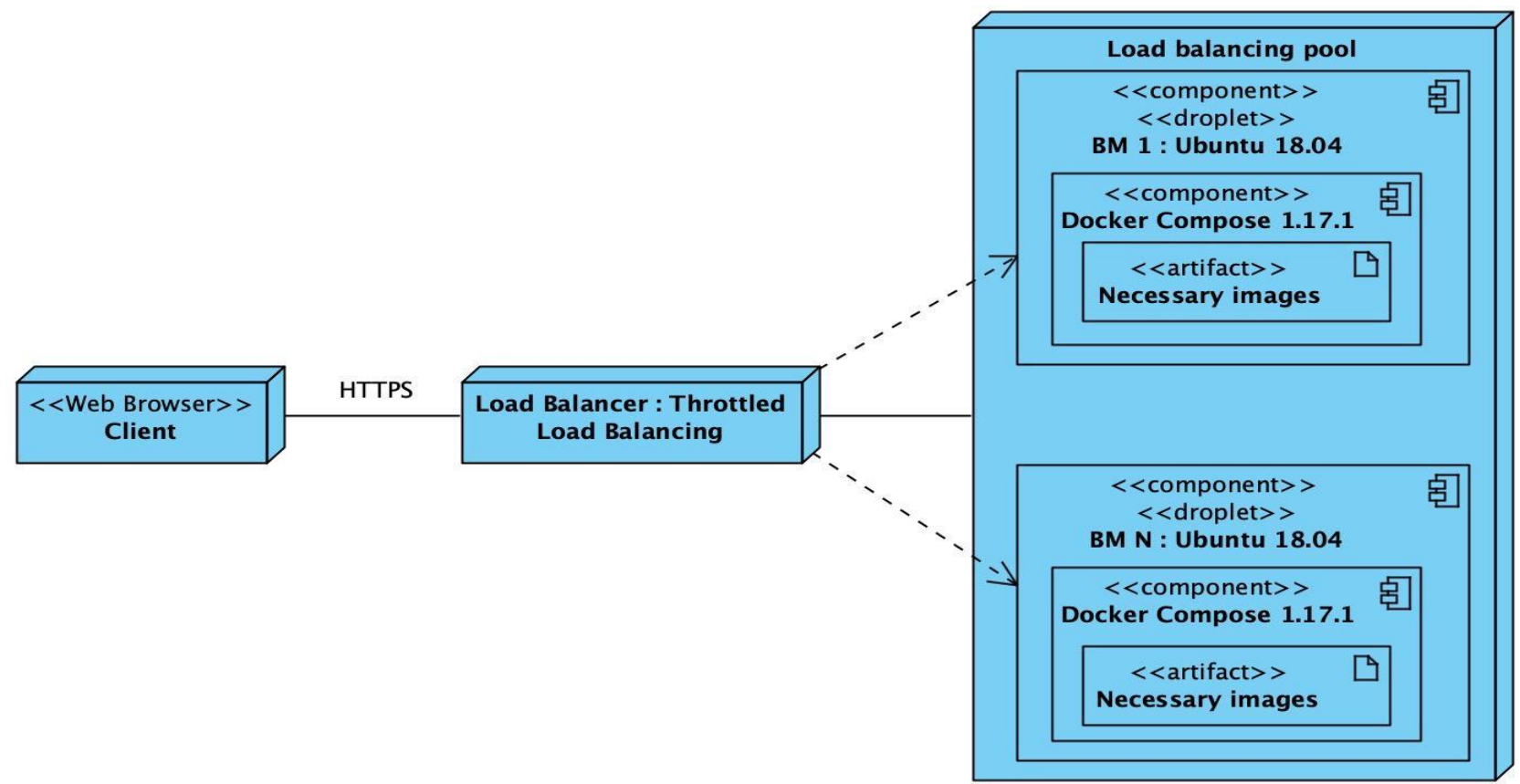

Fig. 3. Web application deployment diagram

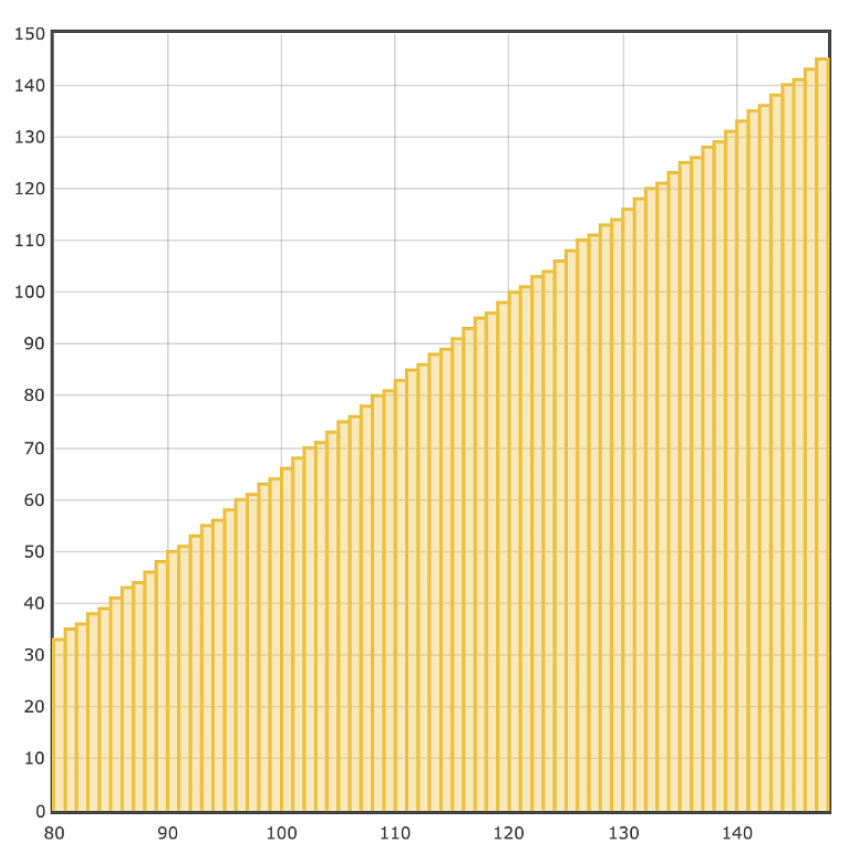

Fig. 4. Efficiency growth

Cloud computing and platforms, scalability, load balancing, virtualization, and deployment through containerization were reviewed during the work. The DigitalOcean platform was investigated their way of providing computing resources with Drop-lets.

As a result of analyzing information on existing technologies, approaches and methods for using cloud platforms in distributed systems, they have been applied to develop a solution to reduce downtime for a distributed adaptive LMS.

\section{References}

1. Sokol V., Tkachuk M., Godlevskiy M., Bilova M., Studenikin D. An Approach to ICT Professionals' Skills Assessment based on European e-Competence Framework. Proceedings of the 16th ICTERI
Conference. Volume II: Workshops. Kharkiv, Ukraine, October 0610, 2020. P. 677-692.

2. Sokol, V. Y., Bronin, S. V., Karnaukh, V. E., Bilova, M. O Developing Adaptive Learning Management Application for Project Team in IT-Industry. Вісник Наи. техн. ун-ту «ХПI» : зб. наук. $n p$. Сер. : Системний аналіз, управління та інформаційні технології. Харків: НТУ «ХПІ», 2020. № 1 (3). С. 97-105.

3. Sokol V. E., Tkachuk M. V., Vasetka Y. M. Adaptive Training System for IT-companies Personnel: Design Principles, Architectural Models and Implementation Technology. Вісник Наи. техн. ун-ту "ХПI» : зб. наук. пр. Сер. : Системний аналіз, управління та інформаиійні технології. Харків: НТУ «ХПІ», 2017. № 51 (1272). C. 38-43.

4. Definition of cloud platform. URL: https://www.pcmag.com/encyclopedia/term/cloud-platform (access date: 13.10 .2020$)$

5. Digital Ocean Hosting: We Review This Host's Big Claims So You Don't Have To. URL: https://www.whoishostingthis.com/hostingreviews/digitalocean/ (access date: 18.10.2020)

6. Volkova V. N., Chemenkaya L. V., Desyatirikova E. N., Hajali M. Khodar A., Osama A. Load balancing in cloud computing. 2018 IEEE Conference of Russian Young Researchers in Electrical and Electronic Engineering (EIConRus). 2018. P. 387-390.

7. Ab Rashid Dar, Ravindran D. Survey On Scalability In Cloud Environment. International Journal of Advanced Research in Computer Engineering \& Technology (IJARCET). 2016. Vol. 5, issue 7. P. 2124-2128.

8. Jain N., Choudhary S. Overview of virtualization in cloud computing 2016 Symposium on Colossal Data Analysis and Networking (CDAN). 2016. P. $1-4$

9. Bokhari M. U., Shallal Q. M., Tamandani Y. K. Cloud computing service models: A comparative study. 2016 3rd International Conference on Computing for Sustainable Global Development (INDIACom). 2016. P. 890-895.

10. Algarni, S. A., Ikbal, M. R., Alroobaea, R., Ghiduk, A. S., Nadeem, F. Performance Evaluation of Xen, KVM, and Proxmox Hypervisors. International Journal of Open Source Software and Processes. 2018. № 9(2). P. 39-54.

11. Maheshwari S., Deochake S., De Ridip, Grover Anish. Comparative Study of Virtual Machines and Containers for DevOps Developers. URL:

https://www.researchgate.net/publication/327237114_Comparative Study_of_Virtual_Machines_and_Containers_for_DevOps_Develop ers (access date: 10.11.2020)

12. Ahmad A. A.-S., Andras P. Measuring and Testing the Scalability of Cloud-based Software Services. 2018 Fifth International Symposium 
on Innovation in Information and Communication Technology. URL https://www.researchgate.net/publication/328768373_Measuring_an d_Testing_the_Scalability_of_Cloud-based_Software_Services (access date: 18.10.2020)

13. Cailliau E., Aerts N., Noterman L., Groote L. A comparative study on containers and related technologies. URL https://www.researchgate.net/publication/320961475_A_comparativ e_study_on_containers_and_related_technologies (access date: 7.10.2020)

\section{References (transliterated)}

1. Sokol V., Tkachuk M., Godlevskiy M., Bilova M., Studenikin D. An Approach to ICT Professionals' Skills Assessment based on European e-Competence Framework. Proceedings of the 16th ICTERI Conference. Volume II: Workshops. Kharkiv, Ukraine, October 0610, 2020. P. 677-692.

2. Sokol, V. Y., Bronin, S. V., Karnaukh, V. E., Bilova, M. O. Developing Adaptive Learning Management Application for Project Team in IT-Industry. Vestnik Nats. tekhn. un-ta "KhPI": sb. nauch. tr. Temat. vyp.: Sistemnyy analiz, upravlenie $i$ informatsionnye tekhnologii [Bulletin of the National Technical University "KhPI": a collection of scientific papers. Thematic issue: System analysis, management and information technology]. Kharkiv, NTU "KhPI" Publ., 2020, no. 1 (3), pp. 97-105.

3. Sokol V. E., Tkachuk M. V., Vasetka Y. M. Adaptive Training System for IT-companies Personnel: Design Principles, Architectural Models and Implementation Technology. Vestnik Nats. tekhn. un-ta "KhPI": sb. nauch. tr. Temat. vyp.: Sistemnyy analiz, upravlenie informatsionnye tekhnologii [Bulletin of the National Technical University "KhPI": a collection of scientific papers. Thematic issue: System analysis, management and information technology]. Kharkiv, NTU “KhPI” Publ., 2017, no. 51 (1272), pp. 38-43.

4. Definition of cloud platform. Available at: https://www.pcmag.com/encyclopedia/term/cloud-platform (access date: 13.10 .2020$)$

5. Digital Ocean Hosting: We Review This Host's Big Claims So You Don't Have To. Available at: https://www.whoishostingthis.com/hosting-reviews/digitalocean/ (access date: 18.10.2020)
6. Volkova V. N., Chemenkaya L. V., Desyatirikova E. N., Hajali M., Khodar A., Osama A. Load balancing in cloud computing. 2018 IEEE Conference of Russian Young Researchers in Electrical and Electronic Engineering (EIConRus). 2018, pp. 387-390.

7. Ab Rashid Dar, Ravindran D. Survey On Scalability In Cloud Environment. International Journal of Advanced Research in Computer Engineering \& Technology (IJARCET). 2016, Vol. 5, issue 7, pp. 2124-2128.

8. Jain N., Choudhary S. (2016). Overview of virtualization in cloud computing. 2016 Symposium on Colossal Data Analysis and Networking (CDAN). 2016, pp. 1-4.

9. Bokhari M. U., Shallal Q. M., Tamandani Y. K. Cloud computing service models: A comparative study. 2016 3rd International Conference on Computing for Sustainable Global Development (INDIACom). 2016, pp. 890-895.

10. Algarni, S. A., Ikbal, M. R., Alroobaea, R., Ghiduk, A. S., Nadeem, F. Performance Evaluation of Xen, KVM, and Proxmox Hypervisors. International Journal of Open Source Software and Processes. 2018, no. 9(2), pp. 39-54.

11. Maheshwari S., Deochake S., De Ridip, Grover Anish. Comparative Study of Virtual Machines and Containers for DevOps Developers. Available https://www.researchgate.net/publication/327237114_Comparative Study_of_Virtual_Machines_and_Containers_for_DevOps_Develop ers (access date: 10.11.2020)

12. Ahmad A. A.-S., Andras P. Measuring and Testing the Scalability of Cloud-based Software Services. 2018 Fifth International Symposium on Innovation in Information and Communication Technology. Available https://www.researchgate.net/publication/328768373_Measuring_an d_Testing_the_Scalability_of_Cloud-based_Software_Services (access date: 18.10.2020)

13. Cailliau E., Aerts N., Noterman L., Groote L. A comparative study on containers and related technologies. Available at: https://www.researchgate.net/publication/320961475_A_comparativ e study_on containers and related technologies (access date: 7.10.2020)

\section{Відомості про авторів / Сведения об авторах / About the Authors}

Сокол Володимир Свгенович - кандидат технічних наук, доцент, Національний технічний університет «Харківський політехнічний інститут», доцент кафедри програмної інженерії та інформаційних технологій управління; м. Харків, Україна; ORCID: https:/orcid.org/0000-0002-4689-3356; e-mail: vlad.sokol@gmail.com

Сапронов Павло Юрійович - Національний технічний університет «Харківський політехнічний інститут», студент; м. Харків, Україна; ORCID: https://orcid.org/0000-0002-9090-6206; e-mail: rairundemps@ gmail.com

Білова Марія Олексї̈вна - кандидат технічних наук, Національний технічний університет «Харківський політехнічний інститут», доцент кафедри програмної інженерії та інформаційних технологій управління; м. Харків, Україна; ORCID: https://orcid.org/0000-0001-7002-4698; e-mail: missalchem@gmail.com

Сокол Владимир Евгеньевич - кандидат технических наук, доцент, Национальный технический университет «Харьковский политехнический институт», доцент кафедры программной инженерии и информационных технологий управления; г. Харьков, Украина; ORCID: https://orcid.org/0000-0002-4689-3356; e-mail: vlad.sokol@gmail.com

Сапронов Павел Юрьевич - Национальный технический университет «Харьковский политехнический институт», студент; г. Харьков, Украина; ORCID: https://orcid.org/0000-0002-9090-6206; e-mail: rairundemps@gmail.com

Белова Мария Алексеевна - кандидат технических наук, Национальный технический университет «Харьковский политехнический институт», доцент кафедры программной инженерии и информационных технологий управления; г. Харьков, Украина; ORCID: https://orcid.org/0000-0001-7002-4698; e-mail: missalchem@gmail.com

Sokol Volodymyr Yevhenovych - PhD, Associate Professor, National Technical University «Kharkov Polytechnic Institute», Associate Professor of the Department of Software Engineering and Management Information Technologies; Kharkiv, Ukraine; ORCID: https://orcid.org/0000-0002-4689-3356; e-mail: vlad.sokol@gmail.com

Sapronov Pavlo Yuriiovych - National Technical University «Kharkov Polytechnic Institute», student; Kharkiv, Ukraine; ORCID: https://orcid.org/0000-0002-9090-6206; e-mail: rairundemps@ gmail.com

Bilova Mariia Oleksiivna - PhD, National Technical University «Kharkov Polytechnic Institute», Associate Professor of the Department of Software Engineering and Management Information Technologies; Kharkiv, Ukraine; ORCID: https://orcid.org/0000-0001-7002-4698; e-mail: missalchem@gmail.com 